\title{
The impact of nutritional status and appetite on the hospital length of stay and postoperative complications in elderly patients with severe aortic stenosis before aortic valve replacement
}

\author{
Dariusz Jagielak ${ }^{1}$, Edyta Wernio ${ }^{2}$, Radosław Kozaryn ${ }^{1}$, Peter Bramlage ${ }^{3}$, Marta Gruchała-Niedoszytko², \\ Jan Rogowski ${ }^{1}$, Sylwia Małgorzewicz ${ }^{2}$
}

${ }^{1}$ Department of Cardiac Surgery, Medical University of Gdansk, Poland

${ }^{2}$ Department of Clinical Nutrition, Medical University of Gdansk, Poland

${ }^{3}$ Institute for Pharmacology and Preventive Medicine, Cloppenburg, Germany

Kardiochirurgia i Torakochirurgia Polska 2016: 13 (2): 105-112

\begin{abstract}
Introduction: Severe aortic stenosis (AS) is associated with the reduction of physical activity and muscle mass and may be associated with decreased appetite.

Aim: To assess the nutritional status and the impact of nutritional status and appetite on the hospital length of stay and postoperative complications in elderly patients with severe AS before aortic valve replacement.

Material and methods: Ninety-nine patients ( 55 male, 44 female; $74.3 \pm 5.2$ years old) with severe AS and an indication for aortic valve replacement (AVR) were included. The nutritional status was assessed by different questionnaires (7-point Subjective Global Assessment Score - 7-SGA, full-Mini Nutritional Assessment - full$\mathrm{MNA}$ ) and anthropometric measurements (body mass index (BMI) $\mathrm{kg} / \mathrm{m}^{2}$ ). Body composition was estimated using multi-frequency bioelectrical impedance analysis. Appetite was assessed by the Simplified Nutrition Assessment Questionnaire (SNAQ).

Results: The average BMI of patients was $28.8 \pm 5.8 \mathrm{~kg} / \mathrm{m}^{2}$. Results of the 7-SGA and f-MNA questionnaires revealed that 39 patients (39.4\%) were at risk of malnutrition. The mean SNAQ score was $15.8 \pm 1.8$. The average length of hospital stay was $10 \pm 5.8$ days. There was a positive correlation of LOS with age $(r=0.26, p=0.03)$ and a negative correlation with fat mass (kg) $(r=-0.28, p=0.04)$ and BMI $(r=-0.22, p=0.03)$. Postoperative complications were observed in 37 patients (37.4\%). Patients who developed complications were older and had poorer nutritional status according to the results of the 7-SGA. Conclusions: Despite many patients undergoing AVR being overweight and obese, a considerable proportion displayed clinical signs of malnutrition. The results suggest that an assessment of nutritional status and appetite in this group of patients should be conducted regularly and that the 7-SGA scale could represent a reliable tool to assess malnutrition.
\end{abstract}

Key words: elderly, aortic stenosis, nutritional status, appetite, body composition.

\section{Streszczenie}

Wprowadzenie: Ciężka stenoza aortalna wiąże się z redukcją aktywności fizycznej, utratą masy mięśniowej i zmniejszeniem apetytu.

Cel: Ocena stanu odżywienia i jego wpływu na czas hospitalizacji oraz częstość występowania powikłań pooperacyjnych u osób w wieku 65 lat i więcej przed leczeniem operacyjnym stenozy aortalnej.

Materiał i metody: Do badania włączono 99 pacjentów (55 mężczyzn, 44 kobiety, średnia wieku: 74,3 $\pm 5,2$ roku) z ciężką stenozą aortalną zakwalifikowanych do leczenia operacyjnego. Stan odżywienia oceniano za pomocą metod kwestionariuszowych (7-point Subjective Global Assessment Score-7-SGA, full-Mini Nutritional Assessment - f-MNA) i antropometrycznych (wskaźnik masy ciała (body mass index - BMI) kg/m²). Skład ciała zbadano metodą bioimpedancji elektrycznej o wielu częstotliwościach. Apetyt oceniono kwestionariuszem SNAQ. Wyniki: Średnia wartość BMI pacjentów wynosiła 28,8 $\pm 5,8$ kg/ $\mathrm{m}^{2}$. Według oceny kwestionariuszami 7-SGA i f-MNA 39 pacjentów $(39,4 \%)$ było zagrożonych niedożywieniem. Średnia wartość SNAQ wynosiła 15,8 $\pm 1,8$. Średni czas hospitalizacji trwał $10 \pm 5,8$ dnia. Stwierdzono pozytywną korelację między czasem hospitalizacji i wiekiem oraz negatywną z masą ciała oraz BMI. Czas trwania hospitalizacji korelował pozytywnie z wiekiem $(r=0,26, p=0,03)$ oraz negatywnie z zawartością tkanki tłuszczowej $(\mathrm{kg})(r=-0,28, p=0,04)$ i wskaźnikiem BMI $(r=-0,22$, $p=0,03)$. Powikłania pooperacyjne zaobserwowano u 37 pacjentów (37,4\%). Pacjenci, u których wystąpiły komplikacje, byli starsi oraz wykazywali gorszy stan odżywienia według skali 7-SGA. Wnioski: Pomimo dużej częstości występowania nadwagi oraz otyłości u znacznej części pacjentów stwierdzono kliniczne objawy niedożywienia. Wyniki wskazują, że ocena stanu odżywienia ze szczególnym uwzględnieniem skali 7-SGA powinna być wykonywana regularnie w tej grupie pacjentów.

Słowa kluczowe: osoby starsze, stenoza aortalna, stan odżywienia, apetyt, skład ciała. 


\section{Introduction}

There is an increasing population of patients aged 65 years which is projected to reach $12 \%$ by the year 2030 [1]. Increasing age is not only associated with cardiovascular risk factors such as diabetes, dyslipidemia, and hypertension [2, 3], but is also associated with a reduction of total and lean body mass. Unintentional weight loss occurs in $15 \%$ to $20 \%$ of those over 65 years, leading to malnutrition and an associated increase in morbidity and mortality [47]. This is because of a change in body composition, being reflective of a reduction of body mass, fat-free mass, and muscle mass. Also there is an increase in fat tissue as well as a significant reduction of taste and smell [4, 8-10].

Malnutrition is particularly evident in hospitalized patients with multiple comorbid diseases and concomitant drug treatment $[4,7,11]$ and is a particular concern in patients with aortic stenosis (AS). It is the most common valve lesion in the elderly population and is present in 2-9\% of subjects over 65 years of age $[12,13]$. Patients with severe aortic stenosis have a very limited life expectancy. The perioperative risk and 30-day mortality are highly dependent on comorbidities such as prior coronary artery bypass graft $(\mathrm{CABG})$, recent myocardial infarction (MI) and low $\left(<20 \mathrm{~kg} / \mathrm{m}^{2}\right)$ or high $\left(>30 \mathrm{~kg} / \mathrm{m}^{2}\right)$ body mass index (BMI) [14]. Furthermore, severe aortic stenosis is associated with the reduction of physical activity and might potentially contribute to a further decrease in appetite, leading to a more rapid weight loss and decrease of muscle mass.

Because of a lack of respective data, the objective of our research was to study the impact of a patient's nutritional status on postoperative complications, the length of hospitalization and survival of elderly patients after aortic valve replacement.

\section{Material and methods}

This was a non-interventional study conducted in the Department of Cardiac and Vascular Surgery of the Gdansk Medical University, Gdansk, Poland. Patients were identified based on a diagnosis of severe aortic stenosis and an indication to undergo aortic valve replacement. It was approved by the responsible ethics committee, and patients consented to their participation.

\section{Nutritional status}

Patients were examined the day before surgery. Nutritional status was evaluated according to: 1) Questionnaires: a) when applying the full Mini Nutritional Assessment (f-MNA) a patient was regarded as well nourished when their f-MNA ranged between 24 and 30 , as being at risk of malnutrition between 17 and 23.5 points and as having malnutrition if the score was less than 17 [15], b) using the 7-point Subjective Global Assessment (7-SGA) patients were regarded as being well nourished between 6 and 7 points, moderately malnourished between 4 and 5 points, and undernourished between 1 and 3 points [16]. 2) We collected anthropometric measures such as body mass index (BMl; $\left.\mathrm{kg} / \mathrm{m}^{2}\right)$ using BMI categories adopted from the MNA norm (malnutrition BMI $<19 \mathrm{~kg} / \mathrm{m}^{2}$, normal BMI $19-24.9 \mathrm{~kg} / \mathrm{m}^{2}$, overweight BMI 25 $29.9 \mathrm{~kg} / \mathrm{m}^{2}$, and obesity BMI $\geq 30 \mathrm{~kg} / \mathrm{m}^{2}$ ) [17]. 3) The evaluation of body composition using the bioelectrical impedance analysis (BIA) method (Maltron BioScan 920-2 Rayleigh, Essex SS6 7XF UK) was used to determine fat mass (FM kg, \%), fat-free mass (FFM kg, \%), extracellular mass/body cell mass ratio (ECM/BCM ratio), body cell mass (BCM kg), extracellular water/intracellular water ratio (ECW/ICW ratio), and excess extracellular water (excess ECW, I). BIA was conducted according to the standards at the bedside, using tetrapolar techniques (hand-foot). 4) The evaluation of the percentage weight loss over the past 6 months.

\section{Assessment of appetite}

Appetite was assessed by the Simplified Nutrition Assessment Questionnaire (SNAQ). A patient scoring $\leq 14$ points was associated with weight loss in 6 months [18].

The duration of hospitalization and postoperative complications were evaluated as well.

\section{Statistical analysis}

Distribution of every variable was assessed with the Shapiro-Wilk test. Continuous variables, depending on the distribution, are given as means \pm standard deviations $( \pm \mathrm{SD})$ or median and ranges. Student's $t$-test was used to compare normally distributed continuous variables, and the Mann-Whitney $U$ test was used for variables without normal distribution. A one-way ANOVA and Kruskal-Wallis ANOVA and post-hoc test Tukey were also used. Analysis of correlations was performed using Pearson and/or Spearman tests where applicable. A p-value of less than 0.05 was considered statistically significant. Statistical analyses were performed with Statistica 10.0 for Windows.

\section{Results}

The study population consisted of 99 elderly patients with aortic stenosis (44 women and 55 men, $74.3 \pm 5.2$ years) and an indication for AVR. Overall $36.4 \%$ of patients had NYHA class II heart failure, $9 \%$ were classified as NYHA II/III and $14 \%$ of patients as NYHA IV. A majority of patients had metabolic risk factors such as hypertension (90.9\%), diabetes (35.4\%), and/or hypercholesterolemia (25.4\%). Coronary artery disease $(65.6 \%)$ was the most frequent comorbidity, followed by chronic kidney disease (11.1\%) and chronic obstructive pulmonary disease (8.1\%) (Table I).

\section{Nutritional status}

According to the f-MNA questionnaire, 39 patients (39.4\%) were at risk of malnutrition, while 60 patients had normal nutritional status. The results of the f-MNA questionnaire positively correlated with the BMI $(r=0.35$, $p=0.003)$, FFM $(\mathrm{kg})(r=0.20, p=0.04)$, FM $(\mathrm{kg})(r=0.26$ $p=0.008)$ and with the results of the SNAQ $(r=0.42$, $p<0.001)$. There were no differences in nutritional status between men and women according to the f-MNA. 
The average result of the 7-SGA questionnaire was 5.5 \pm 0.6 . Thirty-nine patients (39.4\%) were moderately malnourished, and the rest of the patients were well nourished. Moderately malnourished patients had less appetite according to the SNAQ (15.2 \pm 1.8 vs. $16.2 \pm 1.7, p=0.008)$, a lower BMI $\left(25.2 \pm 4.8\right.$ vs. $\left.31.4 \pm 5.4 \mathrm{~kg} / \mathrm{m}^{2}, p<0.001\right)$ and higher ECM/BCM ratio (0.899 \pm 0.048 vs. $0.845 \pm 0.076$, $p<0.001$ ) compared to well-nourished subjects (Table II).

The average BMI of patients was $28.8 \pm 5.8 \mathrm{~kg} / \mathrm{m}^{2}$. A normal BMI was documented in 30 patients (30.0\%). A further 36 patients were overweight (36.0\%) and 33 (33\%) obese. There was no statistically significant difference in BMI between genders (Table III). A positive correlation was, however, observed between BMI and FFM (kg) $(r=0.83$, $p=0.001), \mathrm{FM}(\mathrm{kg})(r=0.85, p<0.001)$, ECW $/ \mathrm{ICW}$ ratio $(r=0.48$, $p<0.001)$ and excess ECW $(r=0.42, p<0.001)$. Body mass index negatively correlated with ECM/BCM ratio $(r=-0.45$, $p<0.001)$ and with length of hospital stay $(r=-0.24$, $p<0.02$ ). We also observed that patients with overweight and obesity had a better nutritional status according to the results of the f-MNA and 7-SGA scale and a lower ECM/BCM ratio than patients with normal weight (Table II).

\section{Unintentional weight loss over the past 6 months}

The median rate of unintentional weight loss over the past 6 months was 0 (range: 0-11.6) and was significantly higher in patients with a normal BMI compared to overweight and obese counterparts $(2.43 \%$ vs. $0 \%$ vs. $0 \%$, respectively; $p=0.006)$. It was also significantly different
Tab. I. Patient characteristics

\begin{tabular}{|c|c|}
\hline Parameter & $\begin{array}{l}\text { All patients }(N=99) \\
n(\%) \text { or mean } \pm \text { SD }\end{array}$ \\
\hline Age [years]: & $74.3 \pm 5.2$ \\
\hline Range & $65-87$ \\
\hline Female gender & $44(44.4)$ \\
\hline \multicolumn{2}{|l|}{ Risk factors: } \\
\hline Diabetes & $35(35.4)$ \\
\hline Hypertension & $90(90.9)$ \\
\hline Hypercholesterolemia & $25(25.4)$ \\
\hline \multicolumn{2}{|l|}{ Comorbid disease: } \\
\hline COPD & $8(8.1)$ \\
\hline Chronic kidney disease & $11(11.1)$ \\
\hline Coronary artery disease & $64(64.6)$ \\
\hline Atherosclerosis of limb & $4(9.4)$ \\
\hline Chronic heart failure & $4(4)$ \\
\hline Atrial fibrillation & $11(11.1)$ \\
\hline Mitral regurgitation & $6(6.1)$ \\
\hline \multicolumn{2}{|l|}{ Procedure performed: } \\
\hline AVR & $59(59.6)$ \\
\hline TAVI & $9(0.1)$ \\
\hline CABG-AVR & $31(31.3)$ \\
\hline
\end{tabular}

COPD - chronic obstructive pulmonary disease, AVR - aortic valve replacement, CABG-AVR - coronary artery bypass graft, TAVI - transcatheter aortic valve implantation.

Tab. II. 7-point subjective global assessment (well-nourished vs. moderate malnourished patients)

\begin{tabular}{|c|c|c|c|}
\hline Parameter & $\begin{array}{l}\text { Well-nourished } \\
\text { (SGA 6-7 points) }\end{array}$ & $\begin{array}{l}\text { Moderately malnourished } \\
\text { (SGA 4-5 points) }\end{array}$ & $P$-value \\
\hline Patient numbers & 60 & 39 & \\
\hline Age [years] & $73.1 \pm 5.1$ & $76.1 \pm 4.9$ & 0.004 \\
\hline Female gender & $26(43.3)$ & $18(46.2)$ & 0.715 \\
\hline BMI $\left[\mathrm{kg} / \mathrm{m}^{2}\right]$ & $31.4 \pm 5.4$ & $25.2 \pm 4.8$ & $<0.001$ \\
\hline SNAQ & $16.2 \pm 1.7$ & $15.2 \pm 1.8$ & 0.008 \\
\hline f-MNA & $26(21.5-29.5)$ & $22.5(17.5-28.5)$ & $<0.001$ \\
\hline LOS [days] & $9.8 \pm 5.3$ & $11.4 \pm 6.5$ & 0.117 \\
\hline$\%$ weight loss 6 months & $0(0-8.3)$ & $2(0-11.3)$ & $<0.001$ \\
\hline Fat-free mass (\%) & $63.2(39.4-81.6)$ & $72.1(42.9-88)$ & $<0.001$ \\
\hline$[\mathrm{kg}]$ & $53.8 \pm 11.8$ & $48.1 \pm 8.3$ & 0.010 \\
\hline ECM/BCM ratio & $0.845 \pm 0.076$ & $0.899 \pm 0.048$ & $<0.001$ \\
\hline $\mathrm{BCM}[\mathrm{kg}]$ & $30 \pm 6.0$ & $25.4 \pm 4.6$ & 0.002 \\
\hline Fat mass (\%) & $36.9(18.4-60.6)$ & $27.8(12-57.1)$ & $<0.001$ \\
\hline$[\mathrm{kg}]$ & $32.1 \pm 12.8$ & $20.9 \pm 10.6$ & $<0.001$ \\
\hline Excess ECW [I] & $0.902 \pm 1.3$ & $0.529 \pm 1$ & 0.139 \\
\hline ECW/ICW ratio & $0.896(0.66-1.139)$ & $0.873(0.627-1.034)$ & 0.284 \\
\hline
\end{tabular}

SNAQ - Simplified Nutrition Assessment Questionnaire, LOS - hospital length of stay, ECW/ICW ratio - extracellular water/intracellular water ratio, ECM/BCM ratio - extracellular mass/body cell mass ratio, BCM - body cell mass; values are presented as mean \pm standard deviation (SD) (continuous variables) or median and range (variables without normal distribution). Statistically significant differences $p<0.05$. 
between patients who were moderately malnourished and well nourished according to the 7-SGA ( $2 \%$ vs. $0 \%$, respectively; $p<0.001)$. A negative correlation was observed between unintentional weight loss and FM (kg) $(r=-0.24$, $p<0.016)$ and positively with ECM/BCM ratio $(r=0.22$, $p=0.27)$.

\section{Duration of hospitalization}

The average length of hospitalization was $10 \pm 5.8$ days. The LOS increased with age $(r=0.26, p=0.03)$. There was no statistically significant difference in the length of hospitalization between the moderately malnourished and well-nourished patients (Table II) or between different BMI groups (Table IV). The LOS negatively correlated with fat mass $(\mathrm{kg})(r=-0.28, p=0.04)$ and BMI $(r=-0.22, p=0.03)$.

\section{Assessment of appetite}

The mean SNAQ score was $15.8 \pm 1.8$. Overall 27 patients (27\%) received less than or equal to 14 points. SNAQ was lower in moderately malnourished compared with well- nourished patients according to the 7-SGA (15.2 \pm 1.8 vs. $16.2 \pm 1.7 ; p=0.008)$.

\section{Postoperative complications}

Postoperative complications were observed in $37 \mathrm{pa}-$ tients (37.4\%). The most common complications after AVR were atrial fibrillation (21.6\%), delirium (18.9\%), respiratory failure (10.8\%), bleeding (10.8\%), cardiac tamponade (10.8\%), renal failure (10.8\%), and pericardial effusion (5\%). Patients developing complications were older and had poorer nutritional status according to the results of the 7-SGA (Table V).

\section{Discussion}

Our study shows a high risk of malnutrition among elderly patients with an indication for AVR. Even though, according to the BMI classification, $70 \%$ of patients were overweight or obese, we diagnosed malnutrition, according to the 7-SGA as well as the f-MNA, in 39\% of patients. The results may call for a regular assessment of nutritional status and appetite in this group of patients and indicate

Tab. III. Assessment of nutritional status according to gender

\begin{tabular}{|c|c|c|c|}
\hline Parameter & Total & Female & Male \\
\hline Patient number & 99 & 44 & 55 \\
\hline $\begin{array}{l}\text { f-MNA [points] } \\
\text { Median (range) }\end{array}$ & $24.5(17.5-29.5)$ & $24.5(18-29.5)$ & $24.5(17.5-29.5)$ \\
\hline $\begin{array}{l}\text { 7-SGA [points] } \\
\text { Mean } \pm \text { SD (range) }\end{array}$ & $5.5 \pm 0.6(4-6)$ & $5.5 \pm 0.7(5-6)$ & $5.5 \pm 0.7(4-6)$ \\
\hline $\begin{array}{l}\text { BMI }\left[\mathrm{kg} / \mathrm{m}^{2}\right] \\
\text { Mean } \pm \text { SD (range) }\end{array}$ & $28.9 \pm 5.8(19.1-50.7)$ & $29.6 \pm 6.2(19.7-50.7)$ & $28.2 \pm 5.4(19.4-41.8)$ \\
\hline $\begin{array}{l}\text { Fat }(\%) \\
\text { Median (range) }\end{array}$ & $33.4(12-60.6)$ & $42.9^{*}(19.8-60.6)$ & $28.4^{\star}(12-46.6)$ \\
\hline $\begin{array}{l}\text { Fat }[k g] \\
\text { Mean } \pm \text { SD (range) }\end{array}$ & $27.8 \pm 13.2(4-78.8)$ & $31.6 \pm 14.3^{\star}(4-78.8)$ & $24.8 \pm 11.5^{\star}(8.1-65.3)$ \\
\hline $\begin{array}{l}\text { Fat-free mass }(\%) \\
\text { Median (range) }\end{array}$ & $65.6(39.4-88)$ & $57^{*}(39.4-80.1)$ & $71.6^{*}(53.4-88)$ \\
\hline $\begin{array}{l}\text { Fat-free mass [kg] } \\
\text { Mean } \pm \text { SD (range) }\end{array}$ & $51.5 \pm 10.8(29.8-81.1)$ & $42.4 \pm 4.9^{\star}(29.8-51.9)$ & $58.7 \pm 8.6^{\star}(40.6-81.1)$ \\
\hline $\begin{array}{l}\text { Body cell mass [kg] } \\
\text { Mean } \pm \text { SD (range) }\end{array}$ & $27.5 \pm 5.8(16.3-43.4)$ & $22.9 \pm 2.9^{*}(16.3-29)$ & $31.3 \pm 4.7^{\star}(21.7-43.4)$ \\
\hline $\begin{array}{l}\text { ECM/BCM ratio } \\
\text { Mean } \pm \text { SD (range) }\end{array}$ & $0.865 \pm 0.072(0.385-1.056)$ & $0.859 \pm 0.072(0.725-1.056)$ & $0.870 \pm 0.719(0.385-0.925)$ \\
\hline $\begin{array}{l}\text { Excess ECW [l] } \\
\text { Median (range) }\end{array}$ & $0(0-5)$ & $0 *(0-4.4)$ & $0.510 *(0-5)$ \\
\hline $\begin{array}{l}\text { ECW/ICW ratio } \\
\text { Median (range) }\end{array}$ & 0.887 (0.627-1.139) & $0.905^{*}(0.627-1.139)$ & $0.870 *(0.660-1.034)$ \\
\hline $\begin{array}{l}\text { SNAQ } \\
\text { Mean } \pm \text { SD (range) }\end{array}$ & $15.8 \pm 1.8(11-20)$ & $15.8 \pm 1.8(11-20)$ & $15.8 \pm 1.9(11-19)$ \\
\hline $\begin{array}{l}\text { LOS [day] } \\
\text { Mean } \pm \text { SD (range) }\end{array}$ & $10 \pm 5.8(1-34)$ & $10.2 \pm 6.2(1-34)$ & $10.6 \pm 5.6(6-29)$ \\
\hline $\begin{array}{l}\% \text { weight loss over the } 6 \text { months } \\
\text { Median (range) }\end{array}$ & $0(0-11.3)$ & $0(0-11.3)$ & $0(0-8.9)$ \\
\hline
\end{tabular}

LOS - hospital length of stay, ECM/BCM ratio - extracellular mass/body cell mass ratio, ECW/ICW ratio - extracellular water/intracellular water ratio, f-MNA - full-Mini Nutritional Assessment, SNAQ - Simplified Nutrition Assessment Questionnaire, FFM - fat-free mass. Values are presented as mean \pm standard deviation (SD) (continuous variables) or median and range (variables without normal distribution). * ${ }^{2}$ tatistically significant differences $p<0.05$. 
Tab. IV. Comparison of patient groups according to body mass index

\begin{tabular}{|c|c|c|c|c|}
\hline Parameter & $\begin{array}{l}\text { Normal weight } \\
19-24.9 \mathrm{~kg} / \mathrm{m}^{2}\end{array}$ & $\begin{array}{c}\text { Overweight } \\
25-29.9 \mathrm{~kg} / \mathrm{m}^{2}\end{array}$ & $\begin{array}{c}\text { Obese } \\
\geq 30 \mathrm{~kg} / \mathrm{m}^{2}\end{array}$ & $P$-value \\
\hline Patient number & 30 & 33 & 36 & \\
\hline Age & $74.9 \pm 5.2$ & $74.1 \pm 5.8$ & $73.8 \pm 4.6$ & 0.608 \\
\hline Female gender & $10(33.3)$ & $14(42.4)$ & $20(55.6)$ & 0.190 \\
\hline f-MNA & $24.5(17.5-29.5)$ & $25.5(21.5-29.5)$ & $25.5(19.5-29.5)$ & 0.001 \\
\hline SNAQ & $15.5 \pm 2$ & $15.6 \pm 1.7$ & $16.2 \pm 1.8$ & 0.285 \\
\hline 7-SGA & $5 \pm 0.6$ & $5.7 \pm 0.5$ & $5.8 \pm 0.3$ & $<0.001$ \\
\hline LOS [day] & $12 \pm 7$ & $10 \pm 5$ & $9 \pm 4.7$ & 0.089 \\
\hline$\%$ WL in 6 months & $2.43(0-11.3)$ & $0(0-5.5)$ & $0(0-8.3)$ & 0.006 \\
\hline Fat-free mass (\%) & $75.2(62.8-88)$ & $66(56-78.4)$ & $55.7(39.4-81.6)$ & $<0.001$ \\
\hline$[\mathrm{kg}]$ & $48.9 \pm 9$ & $51 \pm 9.2$ & $53.9 \pm 13.2$ & 0.293 \\
\hline $\mathrm{ECM} / \mathrm{BCM}$ & $0.907 \pm 0.041$ & $0.870 \pm 0.091$ & $0.826 \pm 0.048$ & $<0.001$ \\
\hline $\mathrm{BCM}[\mathrm{kg}]$ & $25.6 \pm 4.7$ & $27.2 \pm 4.9$ & $29.4 \pm 6.8$ & 0.07 \\
\hline Fat mass (\%) & $24.3(12-37.2)$ & $34(21.6-44)$ & $44.3(18.4-60.6)$ & $<0.001$ \\
\hline$[\mathrm{kg}]$ & $16.3 \pm 4.7$ & $25 \pm 4.3$ & $40 \pm 13.3$ & $<0.001$ \\
\hline ECW/ICW ratio & $0.853(0.627-1.034)$ & $0.886(0.751-1.03)$ & 0.917 (0.660-1.039) & 0.002 \\
\hline Excess ECW [I] & $0(0-4.1)$ & $0(0-2.8)$ & $0.756(0-5)$ & $<0.001$ \\
\hline
\end{tabular}

Tab. V. Comparison depending on process of the surgical procedure (complicated/uncomplicated)

\begin{tabular}{|c|c|c|c|}
\hline Parameter & Complicated & Uncomplicated & $P$-value \\
\hline Patient number & 37 & 62 & \\
\hline Age [years] & $75.9 \pm 4.9$ & $73.2 \pm 5.1$ & 0.01 \\
\hline Female gender & $15(40.5)$ & $29(46.8)$ & 0.55 \\
\hline BMI $\left[\mathrm{kg} / \mathrm{m}^{2}\right]$ & $27.8 \pm 5.5$ & $29.3 \pm 5.9$ & 0.174 \\
\hline SNAQ & $15.7 \pm 2.04$ & $15.8 \pm 1.67$ & 0.843 \\
\hline f-MNA & $24.5(17.5-29.5)$ & $25.3(17.5-29.5)$ & 0.064 \\
\hline 7-SGA & $5.4 \pm 0.7$ & $5.7 \pm 0.5$ & 0.034 \\
\hline LOS [day] & $11.7 \pm 7$ & $9.4 \pm 5$ & 0.009 \\
\hline$\%$ weight loss 6 months & $0(0-9.1)$ & $0(0-11.3)$ & 0.672 \\
\hline Fat-free mass (\%) & $70.5(46.5-88)$ & $65.3(39.4-82.9)$ & 0.332 \\
\hline$[\mathrm{kg}]$ & $50 \pm 7.8$ & $52.4 \pm 12.2$ & 0.643 \\
\hline ECM/BCM ratio & $0.870 \pm 0.052$ & $0.862 \pm 0.081$ & 0.615 \\
\hline BCM [kg] & $26.7 \pm 4.1$ & $28.7 \pm 6.6$ & 0.529 \\
\hline Fat mass (\%) & $29.7(12-53.5)$ & $34.6(17.1-60.6)$ & 0.312 \\
\hline$[\mathrm{kg}]$ & $25 \pm 13.3$ & $29.5 \pm 12.9$ & 0.054 \\
\hline Excess ECW [l] & $0.608(0-4.1)$ & $0.889(0-5)$ & 0.384 \\
\hline ECW/ICW ratio & $0.893(0.660-1.03)$ & $0.886(0.672-1.14)$ & 0.638 \\
\hline
\end{tabular}

SNAQ - Simplified Nutrition Assessment Questionnaire, LOS - hospital length of stay, ECW/ICW ratio - extracellular water/intracellular water ratio, ECM/BCM - extracellular mass/body cell mass ratio, BCM - body cell mass; values are presented as mean \pm standard deviation (SD) (continuous variables) or median and range (variables without normal distribution). Statistically significant differences $p<0.05$. 
that the 7-SGA scale could represent a reliable tool to assess malnutrition.

\section{Association between BMI/nutritional status and outcomes in AVR}

We found that elderly patients with an indication for AVR were mostly overweight (33\%) or obese $(37 \%)$. This is important because of a number of studies showing that a higher $\mathrm{BMI}$ in older patients undergoing AVR is associated with a lower risk of death and postoperative complications [10, 19]. In line with this, Florath et al. reported that a BMI $<24 \mathrm{~kg} / \mathrm{m}^{2}$ was an independent risk factor for 30-day and 6-month mortality after AVR [20].

For the reasons outlined above it is reasonable to hypothesize that the "obesity paradox" may also apply to elderly patients undergoing AVR [2, 21-23]. This paradox has been examined by Kadakia et al. in patients suffering acute coronary syndromes (ACS). The authors were able to show, based on data for 6,560 patients, that overweight and obesity exerted a protective effect up to 30 days after the intervention. Beyond 30 days and until one year of follow-up no protective effect of a higher BMI was seen [24, 25]. Furthermore, there are reports of the "obesity paradox" in patients with heart failure. De Schutter et al. found that the body composition or high FM and FFM, respectively, may also be associated with better survival of patients with heart failure [26]. The data may be speculated to show that patients undergoing AVR with a higher BMI and a proper nutritional status might have a lower risk of perioperative and postoperative complications, including better survival.

Actually our data show that patients with overweight and obesity had a better nutritional status determined by the 7-SGA compared to those with a normal BMI. They also had higher FM and BCM and a lower ECM/BCM ratio, which partly matches the results of De Schutter et al. [26]. The ECM contains all the metabolically inactive tissues, whereas the BCM contains all the metabolically active tissues of the body. The ECM/BCM ratio is a highly sensitive index of malnutrition compared to using the $\mathrm{BMI}$ or FFM alone. This ratio is also a significant independent predictor of mortality in peritoneal dialysis patients $[27,28]$. According to the European Society for Clinical Nutrition and Metabolism (ESPEN), a lower BCM is related to the lack of absorption or lack of nutrient intake, affects the outcome of the underlying disease and may indicate malnutrition [28]. The ECM/BCM ratio is increasingly being used as a sensitive indicator of nutritional status. A high value of this parameter is considered as a predictor for increased mortality and postoperative complications $[28,29]$. The results of the current study indicate that the evaluation of body composition may play an important role in the diagnosis of malnutrition in elderly patients with aortic stenosis. In summary, overweight and obesity in our study were associated with better nutritional status evaluated using one of the most sensitive anthropometric parameters such as the ECM/ $\mathrm{BCM}$ ratio and the 7-SGA scale.
In the current study an unintentional weight loss over six months occurred in $39 \%$ of the patients, and in $14 \%$ of them weight loss exceeded $5 \%$ of body weight. Weight loss in the elderly was associated with poorer nutritional status according to the 7-SGA questionnaire. In addition, a larger reduction in body weight was observed in patients with normal BMI compared to obese and overweight patients. It might be speculated that weight loss greater than $5 \%$ within 6-12 months increases morbidity and mortality. Even a small unintentional weight loss in frail elderly patients can have negative consequences and may enable one to predict functional decline, poorer quality of life, morbidity and follow-up mortality risk [4, 5, 30]. Weight loss of examined patients was related to an increase of ECM/BCM ratio and decrease of FM. That may suggest caloric and protein deficiency in these patients [31-33].

For many elderly patients hospitalization results in functional decline and is associated with complications unrelated to the problem that caused admission [30, 34, 35] In addition, a longer stay in hospital results in higher risk of malnutrition and morbidity and increase costs of hospitalization [34]. In our study the average length of hospitalization was $10 \pm 5.8$ days. Hospital length of stay increased with age. The results of the present study support the hypothesis of other researchers [36, 37].

Obese and overweight elderly subjects were in a better nutritional status than those with normal BMI, but excess weight was associated with a worse hydration status. Compared to elderly subjects with normal body weight, obese and overweight subjects had a higher ECW/ICW ratio. A high BMI was also associated with an excess of ECW. Fluid retention occurred in obese elderly. Similar observations were made in other studies, suggesting also that patients with cardiovascular disease often present an excess of ECW [38].

The evaluation of appetite in our study showed that $27 \%$ of patients were at risk of loss of body weight over six months. Previous studies have demonstrated that a reduction of appetite in the elderly is associated with aging, but also polypharmacy, stress, depression and morbidity may lead to malnutrition $[19,39,40]$. The strong relationship between appetite and nutritional status in elderly hospitalized patients has also been noted by other researchers $[9,10]$. Donini et al. conducted a study on a group of 526 elderly subjects and found that seniors with reduced appetite were in a worse nutritional status according to the MNA, and had a lower BMI compared to those with a better appetite [10]. It seems that evaluation of appetite should accompany other methods of assessment of the nutritional status of elderly patients.

\section{Utility of the 7-SGA questionnaire}

To date, the 7-SGA questionnaire has been mainly used to assess the nutritional status of patients with kidney disease, and malnutrition was strongly associated with an increase in mortality and morbidity $[16,41]$. It has not, however, been used to assess the nutritional status of hospital- 
ized elderly patients with aortic stenosis. Our data show that the 7-point SGA scale correlates well with objective nutritional parameters such as anthropometric measurements (BMI and ECM/BCM ratio) and may indicate a risk of postoperative complications. It is noteworthy that the significance of differences in evaluation of the 7-SGA scale between patients with a complicated/uncomplicated course of surgery was not great. Further investigation on using the 7-SGA scale as a useful tool for the assessment of nutritional status of aortic stenosis in elderly patients should be conducted.

\section{Conclusions}

In older patients undergoing aortic valve replacement, frequently in combination with coronary artery bypass grafting, we found a high proportion of overweight and obese patients and a high risk of malnutrition. In most examined patients there was an unintentional weight loss over the last 6 months and a reduction of appetite. Our research showed that the 7-SGA scale and anthropometric measurements such as BMI and the ECM/BCM ratio appear to be useful and sufficient tools to assess the nutritional status in elderly aortic stenosis patients. We believe that an assessment of nutritional status and appetite in this group of patients should be performed regularly.

\section{Disclosure}

Authors report no conflict of interest.

\section{References}

1. Yan LL, Daviglus ML, Liu K, Pirzada A, Garside DB, Schiffer L, Dyer AR, Greenland P. BMI and health-related quality of life in adults 65 years and older. Obes Res 2004; 12: 69-76 [last access 27.04.2015].

2. Villareal DT, Apovian CM, Kushner RF, Klein S; American Society for Nutrition; NAASO, The Obesity Society. Obesity in older adults: technical review and position statement of the American Society for Nutrition and NAASO, The Obesity Society. Am J Clin Nutr 2005; 82: 923-934.

3. Goulart AC, Rexrode KM. Health consequences of obesity in the elderly: a review. Curr Cardiovasc Risk Rep 2007; 1: 340-347.

4. MCMinn JR, George JN. Evaluation of women with clinically suspected thrombotic thrombocytopenic purpura-hemolytic uremic syndrome during pregnancy. J Clin Apher 2001; 16: 202-209.

5. Alibhai SM, Greenwood C, Payette H. An approach to the management of unintentional weight loss in elderly people. CMAJ 2005; 172: 773-780.

6. Bigaard J, Frederiksen K, Tjønneland A, Thomsen BL, Overvad K, Heitmann BL, Sørensen TI. Body fat and fat-free mass and all-cause mortality. Obes Res 2004; 12: 1042-1049.

7. Newman AB, Yanez D, Harris T, Duxbury A, Enright PL, Fried LP; Cardiovascular Study Research Group. Weight change in old age and its association with mortality. J Am Geriatr Soc 2001; 49: 1309-1318.

8. Ahmed T, Haboubi N. Assessment and management of nutrition in older people and its importance to health. Clin Interv Aging 2010; 5: 207-216.

9. Toffanello ED, Inelmen EM, Imoscopi A, Perissinotto E, Coin A, Miotto F, Donini LM, Cucinotta D, Barbagallo M, Manzato E, Sergi G. Taste loss in hospitalized multimorbid elderly subjects. Clin Interv Aging 2013; 8: 167-174.

10. Donini LM, Poggiogalle E, Piredda M, Pinto A, Barbagallo M, Cucinotta D, Sergi G. Anorexia and eating patterns in the elderly. PLoS One 2013; 8: e63539.

11. Metalidis C, Knockaert DC, Bobbaers H, Vanderschueren S. Involuntary weight loss. Does a negative baseline evaluation provide adequate reassurance? Eur J Intern Med 2008; 19: 345-349.

12. Faggiano P, Antonini-Canterin F, Baldessin F, Lorusso R, D’Aloia A, Cas LD. Epidemiology and cardiovascular risk factors of aortic stenosis. Cardiovasc Ultrasound 2006; 4: 27.
13. Bordoni B, Saia F, Ciuca C, Marrozzini C, Santoro M, Dall'Ara G, Anderlucci L, Montefiori M, Moretti C, Alberti A, Bragagni G, Montori C, Pollastri G, Cocchi D, Marzocchi A; Ricercatori dello Studio ELISA. [Prevalence of degenerative aortic valve stenosis in the elderly: results of a large community-based epidemiological study]. G Ital Cardiol (Rome) 2013; 14: 262-268.

14. Swinkels BM, Vermeulen FE, Kelder JC, van Boven WJ, Plokker HW, Ten Berg JM. Predicting 30-day mortality of aortic valve replacement by the AVR score. Neth Heart J 2011; 19: 273-278.

15. A guide to completing the Mini Nutritional Assessment - Short Form. http://www.mna-elderly.com/forms/mna_guide_english_sf.pdf] [last access 27.04.2015].

16. Visser R, Dekker FW, Boeschoten EW, Stevens P, Krediet RT. Reliability of the 7-point subjective global assessment scale in assessing nutritional status of dialysis patients. Adv Perit Dial 1999; 15: 222-225.

17. Babiarczyk B, Turbiarz A. Body mass index in elderly people - do the reference ranges matter? Prog Health Sci 2012; 2: 58-67.

18. Wilson MM, Thomas DR, Rubenstein LZ, Chibnall JT, Anderson S, Baxi A, Diebold MR, Morley JE. Appetite assessment: simple appetite questionnaire predicts weight loss in community-dwelling adults and nursing home residents. Am J Clin Nutr 2005; 82: 1074-1081.

19. Stanga Z, Allison S, Vandewoude M, Schneider SM, Drozdz Ł. Żywienie osób w wieku podeszłym. In: Podstawy żywienia Klinicznego. IV edn. Sobotka L (ed.). Scientifica, Kraków 2013; 581-617.

20. Florath I, Albert AA, RosendahI UP, Hassanein WM, Bauer S, Ennker IC, Ennker JC. Body mass index: a risk factor for 30-day or six-month mortality in patients undergoing aortic valve replacement? J Heart Valve Dis 2006; 15: 336-344.

21. Lavie CJ, Osman AF, Milani RV, Mehra MR. Body composition and prognosis in chronic systolic heart failure: the obesity paradox. Am J Cardiol 2003; 91: 891-894.

22. Lissin LW, Gauri AJ, Froelicher VF, Ghayoumi A, Myers J, Giacommini J. The prognostic value of body mass index and standard exercise testing in male veterans with congestive heart failure. J Card Fail 2002; 8: 206-215.

23. Zamora E, Lupón J, Urrutia A, Bayes-Genis A. Obesity and long-term prognosis in heart failure: the paradox persists. Rev Esp Cardiol 2010; 63: 1210-1212.

24. Kadakia MB, Fox CS, Scirica BM, Murphy SA, Bonaca MP, Morrow DA. Central obesity and cardiovascular outcomes in patients with acute coronary syndrome: observations from the MERLIN-TIMI 36 trial. Heart 2011; 97: 1782-1787

25. Oreopoulos A, Padwal R, Kalantar-Zadeh K, Fonarow GC, Norris CM, McAlister FA. Body mass index and mortality in heart failure: a meta-analysis. Am Heart J 2008; 156: 13-22.

26. De Schutter A, Lavie CJ, Patel DA, Milani RV. Obesity paradox and the heart: which indicator of obesity best describes this complex relationship? Curr Opin Clin Nutr Metab Care 2013; 16: 517-524.

27. Creditor MC. Hazards of hospitalization of the elderly. Ann Intern Med 1993; 118: 219-223.

28. van Bokhorst-de van der Schueren MAE, Soeters PB, Reijven PLM, Allison SP, Kondrup J, Skowrońska-Piekarska U, Matysiak K. Rozpoznanie niedożywienia - badanie przesiewowe i ocena stanu odżywienia. In: Podstawy żywienia klinicznego. Sobotka L (ed.). Scientifica, Kraków 2013; 23-35.

29. Avram MM, Fein PA, Borawski C, Chattopadhyay J, Matza B. Extracellular mass/body cell mass ratio is an independent predictor of survival in peritoneal dialysis patients. Kidney Int Suppl 2010: S37-S40.

30. Tsai AC, Lai MC, Chang TL. Mid-arm and calf circumferences (MAC and CC) are better than body mass index (BMI) in predicting health status and mortality risk in institutionalized elderly Taiwanese. Arch Gerontol Geriatr 2012; 54: 443-447.

31. Sergi G, Lupoli L, Volpato S, Bertani R, Coin A, Perissinotto E, Calliari I, Inelmen EM, Busetto L, Enzi G. Body fluid distribution in elderly subjects with congestive heart failure. Ann Clin Lab Sci 2004; 34: 416-422.

32. Shizgal HM. The effect of malnutrition on body composition. Surg Gynecol Obstet 1981; 152: 22-26.

33. Huffman GB. Evaluating and treating unintentional weight loss in the elderly. Am Fam Physician 2002; 65: 640-650.

34. Lee JD, Bonaros N, Hong PT, Kofler M, Srivastava M, Herr DL, Lehr EJ, Bonatti J. Factors influencing hospital length of stay after robotic totally endoscopic coronary artery bypass grafting. Ann Thorac Surg 2013; 95: 813-818.

35. Braunschweig C, Gomez S, Sheean PM. Impact of declines in nutritional status on outcomes in adult patients hospitalized for more than 7 days. J Am Diet Assoc 2000; 100: 1316-1322; quiz 23-4. 
36. Wojszel B. Niedożywienie i dylematy leczenia żywieniowego w geriatrii. Post N Med 2011; 8: 649-657.

37. Kostka T (ed.). Starzenie się ludności jako wyzwanie dla lekarzy. PZWL, Warsaw 2009.

38. Barbosa-Silva MC, Barros AJ. Bioelectric impedance and individual characteristics as prognostic factors for post-operative complications. Clin Nutr 2005; 24: 830-838.

39. Kmieć Z, Pétervári E, Balaskó M, Székely M. Anorexia of aging. Vitam Horm 2013; 92: 319-355.
40. Secher M, Ritz P, Vellas B (eds.). Nutrition and aging. 10 ed. Oxford, Wiley Blackwell 2012.

41. de Mutsert R, Grootendorst DC, Boeschoten EW, Brandts H, van Manen JG, Krediet RT, Dekker FW; Netherlands Cooperative Study on the Adequacy of Dialysis-2 Study Group. Subjective global assessment of nutritional status is strongly associated with mortality in chronic dialysis patients. Am J Clin Nutr 2009; 89: 787-793. 